\title{
Analysis of the impact of construction of selected water reservoirs on the surrounding environment made on the basis of satellite data
}

\author{
Boguslawa Kwoczynska ${ }^{1, *}$, Izabela Piech $^{1}$, and Rafal Wozniak ${ }^{2}$ \\ ${ }^{1}$ University of Agriculture in Krakow, Balicka 253a, 30-198 Krakow, Poland \\ ${ }^{2}$ Krakow Office of Geodesy and Agricultural Areas, Gazowa 15, 31-060 Krakow, Poland
}

\begin{abstract}
The authors aimed at showing in the publication the impact of the construction of selected water reservoirs in Poland on the surrounding environment, basing on the satellite imagery. For this purpose, for four test objects, i.e. the Dobczyce Reservoir, the Klimkow Reservoir, the Czorsztyn Reservoir and the Domaniowski Reservoir analyzes were carried out concerning the changes in the structure of land use for the state before and after reservoir construction, and indicators such as NDWI, SAVI and TSAVI were calculated. In the case of the analysis of changes in the land use structure, the direction of these changes was determined first of all, and for SAVI and TSAVI indices, the percentage change in their value and the direction of these changes were calculated.
\end{abstract}

\section{Introduction}

Water is the most important substance for human life. Without it, it's hard to imagine life on Earth, the world of plants or animals. People often waste a lot of it without thinking about the state of resources of this life-giving substance in our country. According to the National Water Management Board, based on data from many years (1951 - 2006), average stocks of flowing waters in Poland amounted to 61.9 billion of $\mathrm{m} 3$ / year, of which the own resources amounted to 54.3 billion of $\mathrm{m} 3$ / year [9]. In addition, there are 2856 lakes in Poland with the area larger than 10 ha and 99 retention reservoirs with the capacity of more than 2 million of $\mathrm{m} 3$. In total, it amounts to 21.7 billion of $\mathrm{m} 3$ [1]. Trying to look at the distribution of water resources in the country, it can be noticed that the most of water is located in the southern Poland.

An important issue in addition to the availability of water, understood as the state of its resources, is its quality. According to the European Environment Agency (EEA), in the case of Poland, the ecological status of 70 $-90 \%$ of water resources is assessed as worse than good [2].

Bearing in mind the above data, the authors asked themselves what to do in such a situation, to take better care of Poland's water resources. A certain remedy for this state of affairs may be the retention reservoirs. The artificial water dams existing currently retain only $6 \%$ of the average annual outflow, which is not enough to protect the country against floods and droughts. The physico-geographical conditions in Poland allow for the storage of nearly $15 \%$ of the annual outflow [1]. There are about 850 water damming facilities in Poland [3].
Water reservoirs in Poland are located mainly in the south of the country, on mountain rivers. In connection with the existing reserve, in the near future construction of further water reservoirs in Poland may be expected. Especially when it comes to the so-called small retention reservoirs. According to [4] and [3], retention is the phenomenon of temporary water holding in the river basin. On the surface of the terrain, the water is accumulated in lakes and water reservoirs, it fills riverbeds valleys and remains in the field hollows, puddles, field furrows.

Taking into account the above-mentioned factors, it is necessary to consider the impact of water reservoirs on the surrounding environment. In the publication, the authors focused primarily on an attempt to analyze this impact basing on data from different sensors, installed on the air platforms (airborne scanning, aerial cameras) and satellite platforms (multispectral scanners).

Applications of satellite imagery in assessing changes occurring in the natural environment for many years is presented both in Polish [5-9] and foreign [1015] literature. However, only a few were involved in the application of remote sensing or photogrammetry to study the impact of building water reservoirs on the environment $[14,16,17]$.

\section{Research work}

\subsection{Satellite remote sensing}

The first human space missions, such as the American missions Mercury, Gemini or Appolo, as well as the Soviet and then Russian Soyuz, can be considered the

\footnotetext{
* Corresponding author: rmkwoczy@cyf-kr.edu.pl
} 
beginning of the satellite remote sensing. Initially, the pictures of our planet were made with the use of handheld cameras that did not provide good quality data [18]. In the case of the Mercury mission - Maurer, Ansco, Robot Recorder or Hasselblad cameras were used for photographing [5].

A milestone in the development of satellite remote sensing was the mission Apollo 9 (March 3 - 13, 1969), in which the experiment consisting in taking multispectral photographs was performed for the first time. For this purpose, 4 Hasselblad cameras synchronized with each other were used, each of them with a film sensitive in a different range of light waves [5]. As a result of this experiment, photographs were taken in panchromatic, green, infrared channels and in the spectroscopic channel. The terrain resolution of the data obtained in this way was $100-130 \mathrm{~m}$ [5]. Initially, satellite images were used similarly to airborne photographs - for the interpretation of elements of the natural environment based on the assessment of the photo features. A certain novum has become the use of so-called Additive Monitors, thanks to which it was possible to assemble an RGB image based on individual scenes in given spectral channels.

After the first manned missions, two Earth observation missions were carried out in parallel in the United States: it was the Landsat mission started in 1972 (continues to this day), and the first orbiting space station SkyLab (1973 - 1974) [5]. The SkyLab station equipment was particularly interesting. It was equipped with a Multispectral ITEK camera (6 cameras equipped with filters: colored, panchromatic, infrared, false-color), high resolution photo camera, infrared spectrometer, multispectral scanner (13 channels), radiometer working in the $\mathrm{K}$ band and the second working in the $\mathrm{L}$ band [5].

At the same time, advanced works on the use of satellite images in the economy were continued in the Union of Soviet Socialist Republics (now Russia) (Vostok 2, Voschod and Soyuz, Salut). These works also did not avoid Europe, where the French SPOT mission (Systeme Pour l'Observation de la Terre), which began in February 1986 is worth mentioning.

Also the European Space Agency established in 1975 , carried out remote sensing missions. One of the first was the Envisat satellite launched in 2002. Its successor was the Sentinel satellite, which has been launched since 2014. There are currently 5 satellites of this mission in space - 2 equipped with MSI multispectral scanners and 2 with SAR radars. Satellites of the Sentinel 3 mission are equipped with various sensors, such as MWR, OLWI, STSLR, and SRAL.

At present, the market of commercial satellites which provide high resolution data is also developing. The beginning of this type of companies should be seen in 1992, when Russia began selling images from KVR1000 and KFA-3000 cameras (resolution 2 - $3 \mathrm{~m}$ ). In 1999, the mission of the Ikonos-2 satellite began. In 2001, DigitalGlobe launched the QuickBird-2 satellite. The satellites of these missions began to provide data at resolutions of about $0.5 \mathrm{~m}$ panchromatically and about 1 $\mathrm{m}$ multispectrally [18]. An example of a modern commercial satellite is WorldView-4, which has a pan- chromatic resolution of $0.31 \mathrm{~m}$ and a multispectral 1.24 $\mathrm{m}$ [19].

\subsection{Landsat mission (1972 - present)}

For the needs of the research, LANDSAT imaging was used. The LANDSAT mission began in 1972 and continues to this day. Currently (May 2017), there are two satellites of this mission in orbit - Landsat 7 and 8 . Table 1 provides basic information on all hitherto LANDSAT missions. The graphics view with the image of particular vehicles are shown in Figure 1.

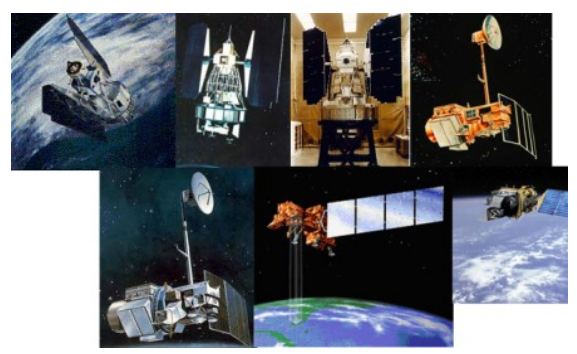

Fig. 1. Landsat mission satellites. Top row from the left: Landsat 1, 2, 3, 4. Bottom row from the right: Landsat 5, 7 i 8. Source: (USGS 2017) [access: 05.06.2017]

Table 1. Basic information on the Landsat mission. Source: (USGS 2017)

\begin{tabular}{|c|c|c|c|}
\hline Satellite & Duration & & Spectral channels \\
\hline $\begin{array}{l}\text { Landsat } \\
1\end{array}$ & $\begin{array}{l}23.07 .1972 \\
6.01 .1978 \\
\end{array}$ & - & $\begin{array}{l}3 \text { RBV scanner and } 4 \\
\text { MSS }\end{array}$ \\
\hline $\begin{array}{l}\text { Landsat } \\
2 \\
\end{array}$ & $\begin{array}{l}22.01 .1975 \\
27.07 .1983 \\
\end{array}$ & - & $\begin{array}{l}3 \text { RBV scanner and } 4 \\
\text { MSS }\end{array}$ \\
\hline $\begin{array}{l}\text { Landsat } \\
3\end{array}$ & $\begin{array}{l}5.03 .1978 \\
7.09 .1983 \\
\end{array}$ & - & $\begin{array}{l}2 \text { RBV scanner and } 5 \\
\text { MSS }\end{array}$ \\
\hline $\begin{array}{l}\text { Landsat } \\
4\end{array}$ & $\begin{array}{l}16.07 .1982 \\
14.12 .1993\end{array}$ & - & 4 MSS scanner and $7 \mathrm{TM}$ \\
\hline $\begin{array}{l}\text { Landsat } \\
5\end{array}$ & $\begin{array}{l}1.03 .1984 \\
5.06 .2013\end{array}$ & - & 4 MSS scanner and $7 \mathrm{TM}$ \\
\hline $\begin{array}{l}\text { Landsat } \\
6 \\
\end{array}$ & $\begin{array}{l}5.10 .1993 \text { (did no } \\
\text { reach the orbit) }\end{array}$ & & 8 ETM scanner \\
\hline $\begin{array}{l}\text { Landsat } \\
7\end{array}$ & $\begin{array}{l}15.04 .1999 \\
\text { currently }\end{array}$ & - & 8 ETM scanner + \\
\hline $\begin{array}{l}\text { Landsat } \\
8\end{array}$ & $\begin{array}{l}11.02 .2013 \\
\text { currently }\end{array}$ & - & 9 OLI scanner and 2 TIRS \\
\hline
\end{tabular}

When describing the capabilities of a given remote sensing system, we often use the following four terms: spatial resolution, spectral resolution, temporal resolution, and radiometric resolution. The first of these terms means the size of a single terrain pixel, or the smallest object possible to be visualized by the sensor. The second is the number of spectral channels and the number of magnetic wavelengths for each channel. The third concept concerns the length of the revisit time over the same point on the Earth. Finally, the last, fourth concept applies to the sensitivity of the sensor, i.e. the number of bits that can be registered. For the 8-bit resolution, it is possible to register values from the range $0-255(28=256)$ [15].

Table 2 presents sample data of sensors installed on the Landsat satellite 8. 
Table 2. Spectral channels with their resolutions fixed on the Landsat 8 satellite. Source: (USGS 2017)

\begin{tabular}{|l|l|c|}
\hline \multicolumn{1}{|c|}{ Channel (sensor) } & $\begin{array}{c}\text { Wave length } \\
{[\mu \mathrm{m}]}\end{array}$ & $\begin{array}{c}\text { Spatial } \\
\text { resolution } \\
{[\mathrm{m}]}\end{array}$ \\
\hline Channel 1 (OLI) & $0.43-0.45$ & 30 \\
\hline Channel 2 (OLI) & $0.45-0.51$ & 30 \\
\hline Channel 3 (OLI) & $0.53-0.59$ & 30 \\
\hline Channel 4 (OLI) - Red & $0.64-0.67$ & 30 \\
\hline Channel 5 (OLI) - nIR & $0.85-0.88$ & 30 \\
\hline Channel 6 (OLI) - SWIR 1 & $1.57-1.65$ & 30 \\
\hline Channel 7 (OLI) - SWIR 2 & $2.11-2.29$ & 30 \\
\hline Channel 8 (OLI) - PAN & $0.50-0.68$ & 15 \\
\hline Channel 9 (OLI) - clouds & $1.36-1.38$ & 30 \\
\hline Channel 10 (TIRS) - TIRS 1 & $10.60-11.19$ & 100 \\
\hline Channel 11 (TIRS) - TIRS 2 & $11.50-12.51$ & 100 \\
\hline
\end{tabular}

\subsection{Characteristics of research objects}

For the purpose of performing the necessary analyzes, being the basis for modelling the impact of a water reservoir construction on the surrounding environment, six test objects were selected: Dobczycki reservoir, Czorsztynski reservoir, Domaniowski reservoir, Klimkowski reservoir, Sieniawa reservoir and Świnna Poręba reservoir (Fig. 2).

As the guiding principle of the selection of test objects, it was assumed that selected artificial reservoirs should not be built earlier than in 1970. This was suggested by the fact that the mission of American remote sensing satellites Landsat, which provide data useful for conducting analyzes has been underway since the 1970 s.

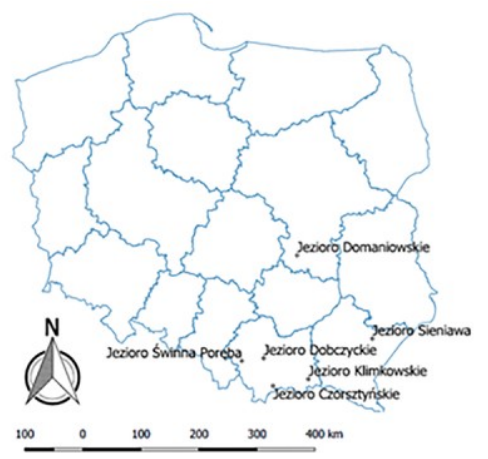

Fig.2. Map of the location of test objects against the background of the country. Source: own elaboration.

\section{Dobczycki Reservoir}

The first of the analyzed reservoirs is Dobczycki Reservoir. It is located in the Myslenice District, in the Malopolskie Voivodeship. It was built in 1986 [3] on the Raba River. The total area of the reservoir is equal 1070 ha, and its total capacity amounts to 125.0 million $\mathrm{m} 3$. The main task of the Dobczycki Reservoir is to supply the city of Krakow with drinking water, therefore, the retention function is completely excluded. In addition, it has a flood control function and in a limited range energy function.
Czorsztynski Reservoir

The second reservoir is the Czorsztynski Reservoir put into use in 1997. This object is located in the Nowy Sacz district, in the Pieniny area. The area of the reservoir is equal 1234 ha, with the total capacity of 231.9 million $\mathrm{m} 3$. The reservoir has primarily energy functions, but it is also a part of the flood protection of the Dunajec Valley. The lake is open to tourists and anglers.

\section{Klimkowski Reservoir}

Klimkowski Reservoir (Klimkowka) was created by building a dam on the Ropa River. Located in the Malopolskie Voivodeship, in the Gorlice district. The reservoir was put into service in 1994. It is much smaller than the previous reservoirs - its area is equal 304 ha, and the capacity amounts to 43.5 million $\mathrm{m} 3$. Its main tasks are flood protection and municipal water supply. To a lesser extent, it has energy and recreational functions.

\section{Sieniawski Reservoir}

It is also known as the Besko water reservoir. The object is located in the Podkarpackie Voivodeship, in the district of Krosno. It was created by building a dam on the Wislok river in 1978. The surface of the created reservoir is equal 126 ha and its total capacity amounts to 13.7 million $\mathrm{m} 3$. The main purpose of the reservoir is the flood protection of the Wislok Valley and the supply of water for the Water Treatment Plant in Sieniawa.

\section{Domaniowski Reservoir}

The Domaniowski reservoir is located in the Masovian Voivodeship, in the Przysucha district on the Radomka River. It was created in 2001. Its total area is equal 500 ha, and the capacity amounts to 9.9 million $\mathrm{m} 3$. The main tasks for this reservoir are flood protection and recreational functions.

\section{Swinna Poreba Reservoir}

The last object is the Świnna Poręba Reservoir. It is located on the Skawa river, in the Wadowicki district, in the Małopolskie voivodship. In 2010, its construction was completed and at the same time its filling started. The planned area of this object is equal 1040 ha, and its planned total capacity is equal 161 million $\mathrm{m} 3$. The reservoir's task will be flood protection of the Skawa river valley and supply of water for municipal purposes [3].

\section{Research methodology}

\subsection{Unattended classification method}

To study the phenomenon of the impact on the environment of newly constructed water reservoirs, the best suited are the multispectral imaging and various methods for classifying these data. The research focused mainly on unattended methods, and more specifically on K-means clustering (k-means, centroid algorithm) and ISODATA. 


\subsubsection{Method $K-$ means clustering $(k-$ means, centroids algorithm)}

For this algorithm, the $\mathrm{K}$ value is determined first, denoting the number of clusters (groups of objects with similar properties or values). Then the preliminary initialization of the values of clusters, i.e. the calculation of their average values is performed. In the next steps, each point is assigned to a given cluster by iteration method, and its average value is recalculated. Thanks to this procedure, the average "wanders" to the center of the cluster.

The computational complexity of the presented algorithm can be calculated using the formula (1):

$$
O=n \cdot K \cdot l \cdot d
$$

where: $n$ - number of points, $K$ - number of clusters, 1 number of iterations, $\mathrm{d}$ - number of attributes.

In the case of implementation of this algorithm for the purposes of classification of remote sensing data, the number of clusters, or the concept of a cluster is extremely intuitive, because in this case clusters mean a given form of land use. A certain drawback associated with the classification is the necessity to declare the number of clusters before the algorithm is executed.

In $\mathrm{K}$ - means method previously, the optimal number of clusters should be assumed. This can be done by trying to determine various forms of land development using different combinations of spectral channels forming on the RGB composition, highlighting the given terrain form. Then, in order to optimize the process of image processing, the large scenes from remote sensing satellites can be cut according to the research area. The last recommendation applies to the maximum number of iterations, however, the selection of the optimal value must be preceded by a previous examination and comparison of effects for different values.

\subsubsection{ISODATA}

The second method of unsupervised classification used in the carried out research is the ISODATA method (Iterative, Self-Organizing, Data Analysis Technique aYa). Unlike in the K-means method, it is not necessary to provide the number of clusters at the beginning of the analysis. The algorithm combines and divides clusters.

In the first step, the centers of clusters are arranged randomly, and the points are allocated on the basis of the closest distance to the centers. Then, the standard deviation is calculated for each of the clusters. If its value is greater than the assumed distance, the cluster is divided. If the deviation is smaller than assumed, then two clusters are combined into one. After this procedure is finished, another iteration is performed.

The entire algorithm is aborted if one of the three situations occurs: the average distance between cluster centers is smaller than the assumed value; the size of changes in the distance between centers in subsequent iterations is smaller than assumed and finally the maximum number of iterations is reached [20].
The ISODATA algorithm has the advantage over Kmeans that the number of clusters is automatically selected.

While analyzing changes in the land use structure, which may be affected by the construction of a water reservoir, the following methodology was used:

- Determination of the area to be analyzed - it was assumed that the area would be within $500 \mathrm{~m}$ from the shoreline of the reservoir. This is caused by the desire to focus only on the impact of the water body itself, so areas located further could falsify the results of research.

- Cutting the raster files containing individual spectral channels.

- Performing the classification unattended by the $\mathrm{k}$ means method and the ISODATA method (in the case of the first method, additional post-processing was necessary).

- Two analyzes were performed for each research area - for the state before construction and after the construction of the water reservoir.

- Preparation of the statement of the results in tabular form.

\subsection{Indices: NDWI, SAVI and TSAVI}

Besides the NDWI index, or the NDVI index, which is popular in remote sensing, the subject literature mentions other useful indices. Some of them can be mentioned here, for example PVI (Perpendicular Vegetation Index), RVI (Ratio Vegetation Index), SARVI (Soil Adjusted Ratio Vegetation Index) or SAVI (Soil Adjusted Vegetation Index) and TSAVI (Transformed Soil Adjusted Vegetation Index) [12]. In the course of further research on the impact of the construction of water reservoirs on the environment, the authors focused on using the last two indices to assess this impact.

\subsubsection{NDWI}

The remote sensing of the natural environment has many applications. One of them is monitoring of the plants condition or estimating the size of crops and determining the amount of biomass [11]. For this purpose, various indices calculated on the basis of the values of the respective spectral channels are used. One of them is NDVI (The Normalized Difference Vegetation Index) [21]. This index uses the contrast between the reflection in the near-infrared band (NIR), and absorption in the red band (RED). It can be expressed using the formula (2):

$$
N D V I=(N I R-R E D) /(N I R+R E D)
$$

A certain drawback of this index is the different ability to penetrate vegetation by the both bands. Close infrared can penetrate up to 8 layers of leaves, while the red channel only 1 or less [22]. Bearing in mind these defects of the NDVI index, and wishing to focus more on the detection of liquid water in vegetation, [17] proposed a new index called NDWI (Normalized 
Difference Water Index). Its calculation uses two infrared spectral channels with wavelengths close to 0.86 and $1.24 \mu \mathrm{m}$. This index is given by the formula (3):

$$
N D W I=[B(0.86)-B(1.24)] /[B(0.86)+B(1.24)]
$$

Where $\mathrm{B}(0.86)$ and $\mathrm{B}(1.24)$ mean spectral channels with wavelengths given in brackets. This index takes values from -1 to 1 , where the higher the value, the higher the water content. According to [17], open soils in most cases have negative values, but close to 0 .

The NDWI index can have many applications, ranging from drought monitoring [14], to analysis of water stress in plants, etc. However, according to [17], NDWI also has some disadvantages that should be kept in mind. In addition to water in plants, the value of this index is also influenced by factors such as soil, pesticides or plant diseases. For this reason, other tools should be considered in addition to using the NDWI index.

The authors adopted the assumption that the construction of a water reservoir will have an impact on the surrounding environment also by changing soil moisture and water availability for plants. Therefore, it was decided to check the change in the value of the index before and after the construction of the reservoir.

Similarly to the analysis of changes in the structure of land use, also here it was decided to limit the area to $500 \mathrm{~m}$ from the borders of the reservoir. For the such determined area, an NDWI map was developed and assumption was made to calculate the mean values of the index for selected test fields located in different places around the reservoir.

\subsubsection{SAVI}

SAVI was calculated to minimize the impact of the brightness of soil images on the results of vegetation indices [23]. Its calculation uses data from two spectral channels: near infrared (NIR) and red (RED). Furthermore, the parameter $\mathrm{L}$ was added as a modification of the previous (NDVI) index. It depends on land cover, and for soil not covered with vegetation, the value of 1 is assumed, whereas for full coverage 0 [23]. For average conditions, the value $L=0.5$ should be taken [13]. The index takes values from - 1 to 1 , whereas, the closer to 1 , the better is the vegetation. In order to calculate the SAVI index, we use the formula (4):

$$
S A V I=[(1+L) \cdot(N I R-R E D)] /(N I R+R E D+L)
$$

Where NIR and RED are appropriate spectral channels (for Landsat 8 they are respectively channels 5 and 3, and for Landsat 5 channels 4 and 2), and the parameter L, as already mentioned, assumes a value of 0.5 .

\subsubsection{TSAVI}

The TSAVI index was developed as a modification of the formula (4). The main idea of the creator of this index was the desire to closely correlate the vegetation index with such indices as LAI (Leaf Area Index) or APAR (photosynthetically active radiation absorber by the canopy) [24]. This index is given by the formula (5):

$$
T S A V I=[a \cdot(N I R-a \cdot R E D-b)] /(R E D+a \cdot N I R-a \cdot b)
$$

where $\mathrm{a}=0.96916$ and $\mathrm{b}=0.084726$. TSAVI takes values from 0 for soil not covered by vegetation up to 1 for a very high value of LAI, ie rich vegetation [24].

As in the previous cases, analyzes of the state before and after construction of water reservoirs were performed to determine their impact on the values of indices. Analyzes were made as before for four test objects, i.e. Dobczycki, Czorsztynski, Klimkowski and Domaniowski reservoirs. The same test fields as for the NDWI analyses were used. When calculating the SAVI value, for the $\mathrm{L}$ parameter the value $\mathrm{L}=0.5$ was assumed. All results were collected in the appropriate tables.

\section{Results}

From the initially selected reservoirs, the Sieniawski Reservoir was excluded (due to the small area) and the Świnna Poręba Reservoir (because of its lack of filling the lake has not yet reached the planned surface, so it is not possible to talk about its impact here, at least about the study of the impact on the environment).

Initially, according to the presented methodology, it was planned for each reservoir to perform analyzes before filling and for 2016 using K-means and ISODATA methods. However, after visual analysis of the results obtained with the latter method, it was decided to exclude it from the further analyzes.

Also, after analyzing the results for the Czorsztynski Reservoir, it was considered that it should be excluded, because incorrect results could have a significant negative impact on the results of the entire experiment. An example of incorrect classification for the Czorsztynski Reservoir is shown in Figure 3. Finally, three reservoirs were taken into consideration: Dobczycki, Klimkowski and Domaniowski.

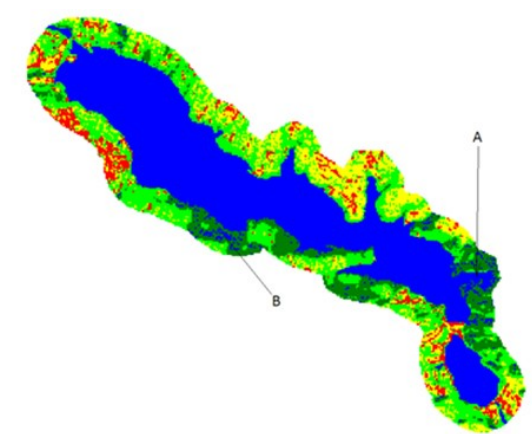

Fig. 3. Erroneous classification of the unattended Czorsztyn Lake. Source: own elaboration.

The method $\mathrm{K}$ - means used here, gave incorrect classification. Two areas are noteworthy - A, being a hill with the Czorsztyn castle, erroneously classified as a water surface area, and B - area of the beach at the lake. 
Table 3. The summary of the results of analyzes of changes in the structure of agricultural land before and after the construction of water reservoirs. Source: own study.

\begin{tabular}{|c|c|c|c|c|c|c|c|c|c|}
\hline \multirow{2}{*}{ Type of use } & \multicolumn{3}{|c|}{ Dobczycki Reservoir } & \multicolumn{3}{c|}{ Klimkowski Reservoir } & \multicolumn{3}{c|}{ Domaniowski Reservoir } \\
\cline { 2 - 12 } & $\begin{array}{c}1984 \\
{[\mathrm{ha}]}\end{array}$ & $\begin{array}{c}2016 \\
{[\mathrm{ha}]}\end{array}$ & $\begin{array}{c}\text { Change } \\
\%\end{array}$ & $\begin{array}{c}1984[\mathrm{ha}] \\
{\left[\begin{array}{c}2016 \\
{[\mathrm{ha}]}\end{array}\right.}\end{array}$ & $\begin{array}{c}\text { Change } \\
\%\end{array}$ & $\begin{array}{c}1994 \\
{[\mathrm{ha}]}\end{array}$ & $\begin{array}{c}2016 \\
{[\mathrm{ha}]}\end{array}$ & $\begin{array}{c}\text { Change } \\
\%\end{array}$ \\
\hline Forest areas & 413.46 & 622.98 & 50.67 & 376.38 & 415.80 & 10.47 & 287.64 & 278.37 & -3.22 \\
\hline Urbanized areas & 24.39 & 175.59 & 619.93 & 11.52 & 20.16 & 75.00 & 0.00 & 3.06 & - \\
\hline Agricultural areas & 592.56 & 272.70 & -53.98 & 97.47 & 114.93 & 17.91 & 248.13 & 186.75 & -24.74 \\
\hline $\begin{array}{c}\text { Meadows and } \\
\text { pastures }\end{array}$ & 498.87 & 225.00 & -54.90 & 178.02 & 87.57 & -50.81 & 104.04 & 33.75 & -67.56 \\
\hline Thicket and wasteland & 32.22 & 260.28 & 707.82 & 9.54 & 34.47 & 261.32 & 51.75 & 124.11 & 139.83 \\
\hline Water & 823.32 & - & - & 212.85 & - & - & 277.92 & - & - \\
\hline
\end{tabular}

\subsection{Analysis of the land use changes around selected water reservoirs}

For each analysis, the necessary step was to identify spectral homogeneous areas identified in the unattended classification process. To accomplish this, two sources were used - orthophotomap (mainly for the current state of use) and a color combination, created by assigning appropriate spectral channels to RGB colors. Using the properties of certain objects, which consists in differentiation of the absorption of different wavelengths of light, it is possible to create images that enhance some forms of space management in a simple way through an appropriate combination (Fig. 4).

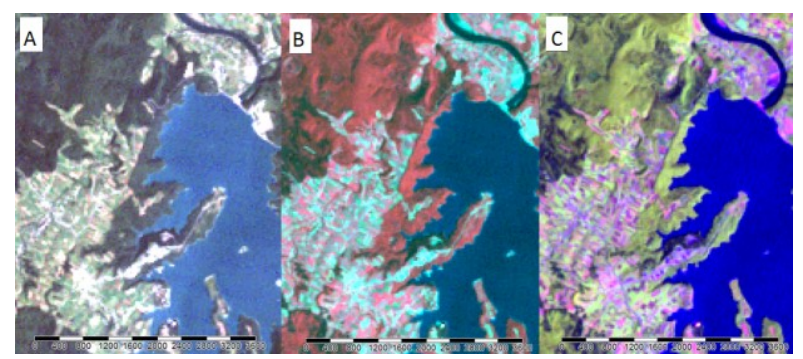

Fig. 4. Different colour combinations of the Landsat channels: A - 321, B - 432, C - 541. Source: own elaboration.

Table 3 presents the results of analyzes of changes in land use for the three analyzed areas.

Analyzing the obtained results, it can be noticed that in the case of both Dobczycki and Klimkowski Reservoirs, there was an increase in the area occupied by forests, respectively by 50 and $10 \%$ in relation to the initial state. Only in the case of the Domaniowski Reservoir there was a loss of forest areas, but this is about $3 \%$, and in the opinion of the authors, this can be considered as an error related to the classification.

At the same time, in each case an increase in urbanized areas was noted, the greatest around the Dobczycki reservoir (nearly 620\%), but this can be explained by the proximity of the city in relation to Krakow and increased construction pressure on the part of the inhabitants of this city. Another interesting analysis is the reduction in the area of land occupied by meadows and pastures (by about $50-67 \%$ ), and the reduction of agricultural land. Only in the case of the Klimkowski reservoir, this area has slightly increased (nearly $18 \%$ ). Along with the reduction of land area related to agriculture, the area of wastelands and thicket increases. The largest percentage share was recorded in the case of the Dobczycki Reservoir and it amounted to over $700 \%$ in relation to the initial state.

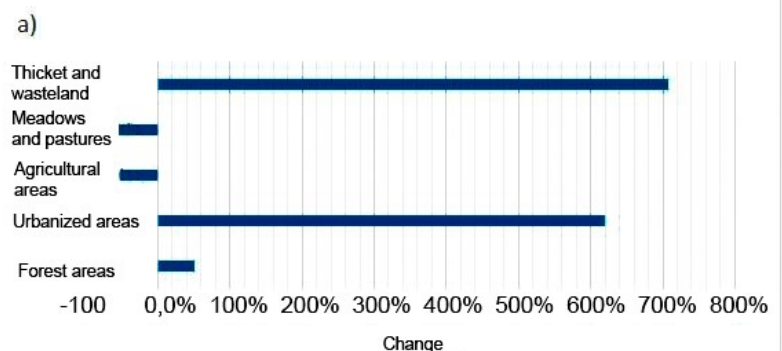

b)

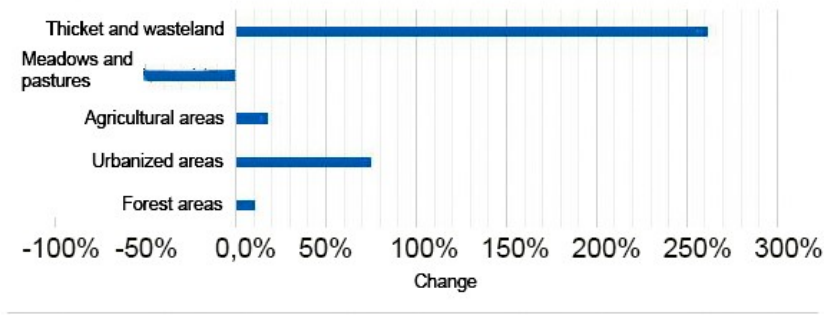

c)

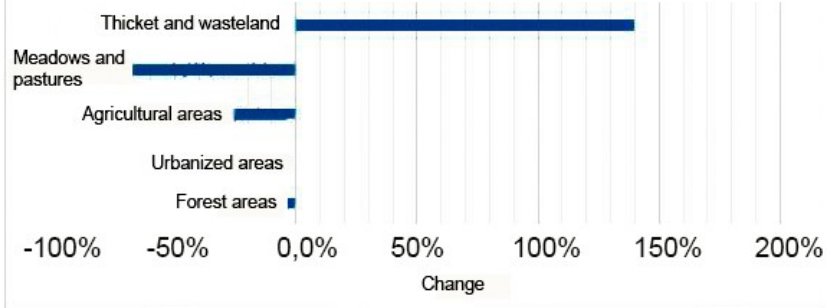

Fig. 5. The dynamics of changes in land use around water reservoirs a) Dobczycki Reservoir; b) Klimkowski Reservoir; c) Domaniowski Reservoir. Source: own elaboration. 
In order to better present the data, the results were provided in the form of diagrams (Fig. 5), where the dynamics of changes are presented, and the selected land cover maps are show on the drawings 6-8.

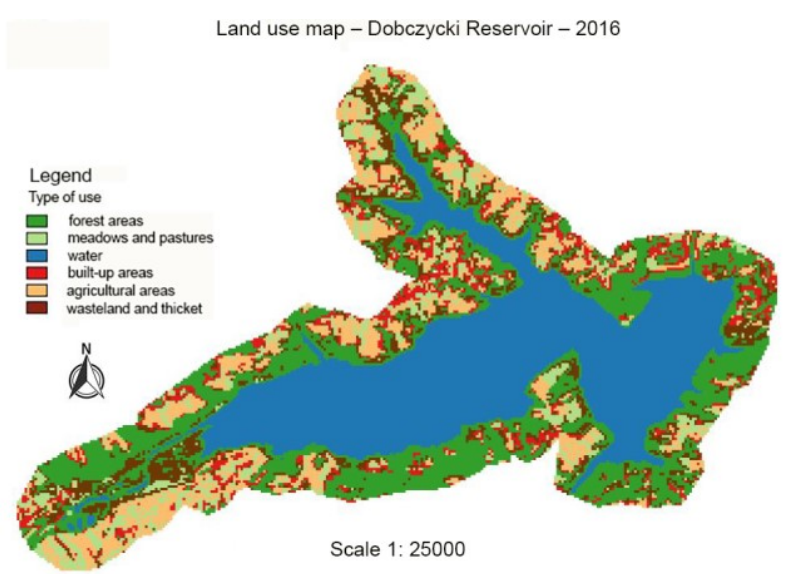

a/

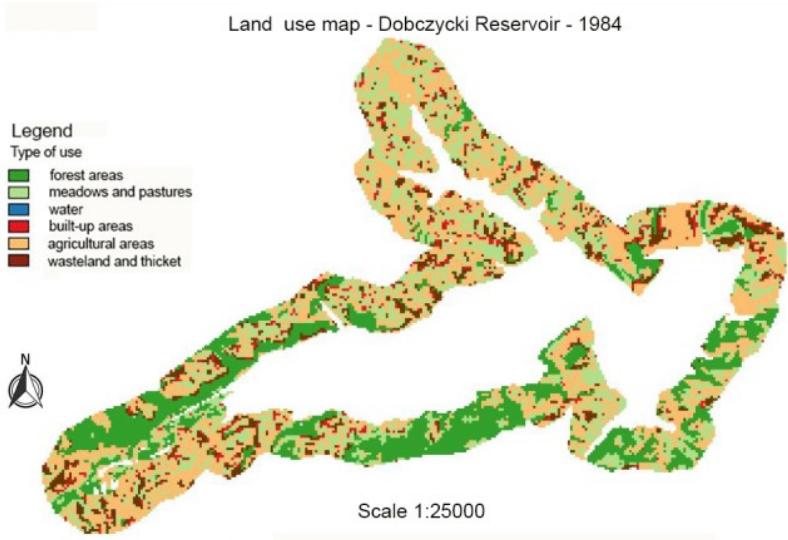

b/

Fig. 6. The map of land use around the Dobczycki Reservoir made on the basis: a/ Landsat 8 satellite from 2016, b/ Landsat 5 satellite from 1984

\subsection{Analysis of the NDWI index changes for selected water reservoirs}

In order to examine the changes in the NDWI index, calculations were made for 3 water reservoirs: Dobczycki, Klimkowski and Domaniowski Reservoirs. Two analyzes were performed for each of them: the state before the construction of the reservoir and the state after its construction. Thanks to this, it was possible to determine the change in water content in plants. For each reservoir, test fields located in the test area were selected, i.e. in the buffer zone of $500 \mathrm{~m}$ from the reservoir borders (Fig. 9).

Not the same number of test fields resulted from the size of reservoirs and their shapes.

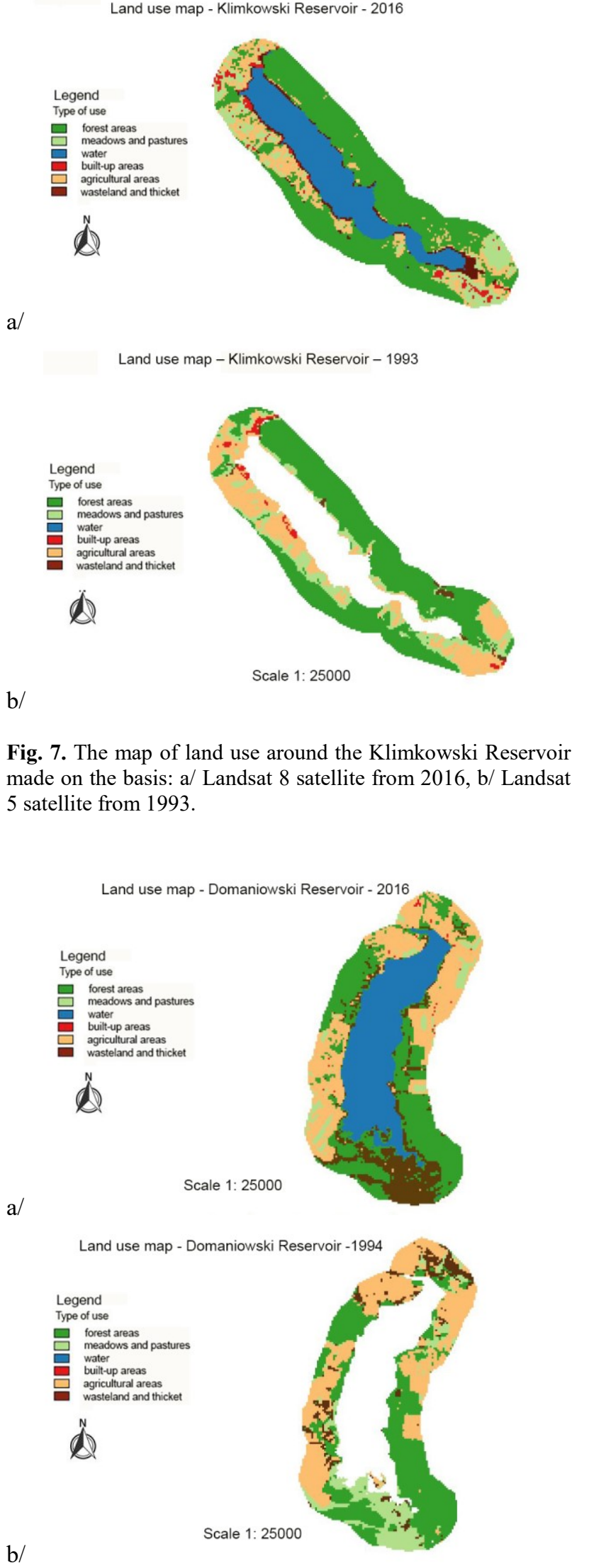

Fig. 8. The map of land use around the Domaniowski Reservoir made on the basis: a/ Landsat 8 satellite from 2016, b/ Landsat 5 satellite from 1994. 
Table 4. Changes in the value of the NDWI index for the examined objects. Source: own elaboration.

\begin{tabular}{|c|c|c|c|c|c|c|c|c|c|c|c|c|}
\hline \multirow[b]{2}{*}{ field } & \multicolumn{4}{|c|}{ Dobczycki Reservoir } & \multicolumn{4}{|c|}{ Klimkowski Reservoir } & \multicolumn{4}{|c|}{ Domaniowski Reservoir } \\
\hline & $\begin{array}{l}\text { Area } \\
{[\mathrm{ha}]}\end{array}$ & $\begin{array}{c}\text { NDWI } \\
1984 \\
\end{array}$ & $\begin{array}{c}\text { NDWI } \\
2016 \\
\end{array}$ & $\begin{array}{c}\text { Change } \\
\%\end{array}$ & $\begin{array}{l}\text { Area } \\
{[\mathrm{ha}]}\end{array}$ & $\begin{array}{c}\text { NDWI } \\
1993 \\
\end{array}$ & $\begin{array}{c}\text { NDWI } \\
2016 \\
\end{array}$ & \begin{tabular}{|c|} 
Change \\
$\%$
\end{tabular} & $\begin{array}{l}\text { Area } \\
{[\text { ha] }}\end{array}$ & \begin{tabular}{|c|} 
NDWI \\
1994 \\
\end{tabular} & $\begin{array}{c}\text { NDWI } \\
2016 \\
\end{array}$ & $\begin{array}{c}\text { Change } \\
\%\end{array}$ \\
\hline 1 & 3.4556 & -0.4173 & -0.2972 & 28.76 & 7.7730 & -0.3883 & -0.2953 & 23.95 & 13.0585 & -0.3337 & -0.3015 & 9.64 \\
\hline 2 & 1.8313 & -0.3921 & -0.2819 & 28.12 & 7.3659 & -0.4291 & -0.2842 & 33.78 & 5.4163 & -0.2631 & -0.2336 & 11.20 \\
\hline 3 & 3.7416 & -0.2676 & -0.2755 & -2.96 & 5.6728 & -0.5181 & -0.3979 & 23.21 & 9.0832 & -0.2963 & -0.2010 & 32.16 \\
\hline 4 & 9.1433 & -0.3842 & -0.2809 & 26.88 & 7.3664 & -0.4506 & -0.2569 & 42.99 & 12.1085 & -0.2993 & -0.1991 & 33.48 \\
\hline 5 & 13.3009 & -0.3771 & -0.3325 & 11.83 & 10.0902 & -0.4865 & -0.3603 & 25.95 & 9.8110 & -0.2447 & -0.1893 & 22.64 \\
\hline 6 & 4.0952 & -0.4269 & -0.2972 & 30.37 & - & - & - & - & 16.2587 & -0.4027 & -0.2532 & 37.12 \\
\hline 7 & 5.2073 & -0.4574 & -0.3510 & 23.25 & - & - & - & - & - & - & - & - \\
\hline average & & -0.3889 & -0.3023 & 20.89 & & -0.4545 & -0.3189 & 29.97 & & -0.3066 & -0.2296 & 24.38 \\
\hline
\end{tabular}

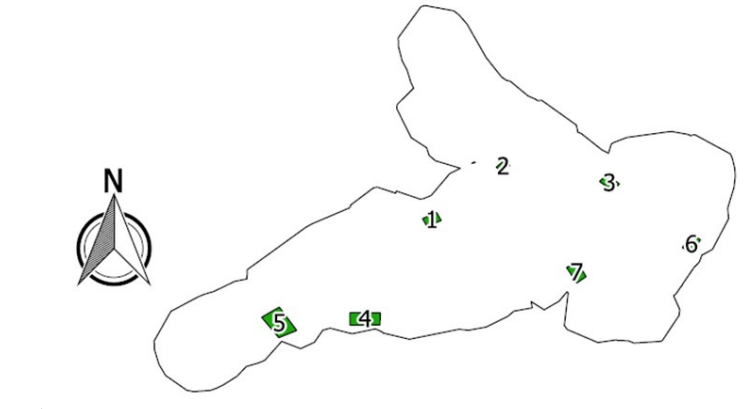

a/

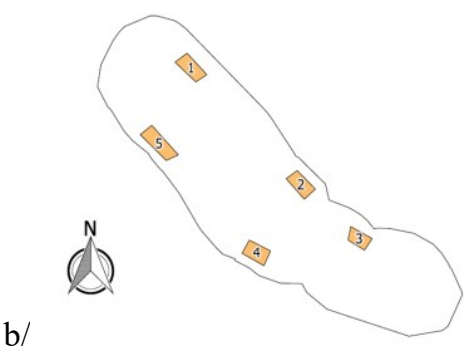

c/

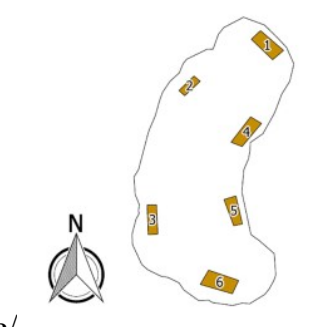

Fig. 9. The map of the test fields locations for the object: a/ Dobczycki Reservoir, b/ Klimkowski Reservoir, c/ Domaniowski Reservoir. Source: own elaboration.

For each of the test fields, the average value of the NDWI index for the state before and after the reservoir construction was calculated and the area of each field was calculated. The results are summarized in Table 4. Moreover, the list includes the change in the value of the index as a percentage, to show the dynamics of changes.

Summarizing the values collected from analyses for the 3 research objects, it should be noted that for each of them a change in the NDWI value was noted by about $20-30 \%$ in relation to the initial state, i.e. before the construction of the water reservoir.
Moreover, in each case it was a change that allows to state that the amount of water in plants has increased. However, due to the small number of analyzes for a single object, the far-reaching conclusions should be formulated carefully. In order to confirm or refute the thesis about the correlation between the construction of the reservoir and the increase of the NDWI value, it is necessary to perform analyzes for the possibly long period to calculate the average from many years. As in the case of the Landsat mission satellites there is a regular return time over the same area, it is the analysis of time series. Such analysis will give the final answer to the question about the correlation for the NDWI index. However, the authors believe that this work gives encouraging results for the further research.

\subsection{Analysis of changes in the SAVI and TSAVI indices for the selected water reservoirs}

As in previous cases, analyzes of the state before and after construction of water reservoirs were made to determine their impact on the value of the index. Analyzes were made as before for three test objects, i.e. Dobczycki, Klimkowski and Domaniowski Reservoirs.

The same test fields as for the NDWI analyses were used. When calculating the SAVI value, the L parameter value was assumed $L=0.5$. All results were collected in the appropriate tables (Tab. 5 and 6).

Summarizing the SAVI and TSAVI analyzes, a decrease in the value of indices was observed for all three test objects. These changes ranged from approx. $24 \%$ to approx. $29 \%$ for the first index and from 21 to $43 \%$ for TSAVI. As in the case of the NDWI index discussed earlier, before the final conclusions are drawn, analyzes for a longer period should be performed and only on the basis of multi-year results compiled with similar ones obtained for comparative objects (ie for which no water reservoir acted), the final thesis can be formulated. 
Table 5. The results of SAVI and TSAVI analyzes for

Dobczycki and Klimkowski reservoirs. Source: own research.

\begin{tabular}{|c|c|c|c|c|c|c|c|c|c|c|c|c|}
\hline \multirow{2}{*}{$\begin{array}{l}\text { Test } \\
\text { field }\end{array}$} & \multicolumn{6}{|c|}{ Dobczycki Reservoir } & \multicolumn{6}{|c|}{ Klimkowski Reservoir } \\
\hline & $\begin{array}{c}\text { SAVI } \\
1984\end{array}$ & $\begin{array}{l}\text { SAVI } \\
2016\end{array}$ & $\begin{array}{c}\text { Change } \\
\%\end{array}$ & $\begin{array}{c}\text { TSAVI } \\
1984\end{array}$ & $\begin{array}{c}\text { TSAVI } \\
2016\end{array}$ & $\begin{array}{c}\text { Change } \\
\%\end{array}$ & $\begin{array}{l}\text { SAVI } \\
1993\end{array}$ & $\begin{array}{l}\text { SAVI } \\
2016\end{array}$ & $\begin{array}{c}\text { Change } \\
\%\end{array}$ & $\begin{array}{c}\text { TSAVI } \\
1993\end{array}$ & $\begin{array}{c}\text { TSAVI } \\
2016\end{array}$ & $\begin{array}{c}\text { Change } \\
\%\end{array}$ \\
\hline 1 & 0.6237 & 0.4459 & -39.88 & 0.4220 & 0.3047 & -27.80 & 0.5793 & 0.4430 & -23.53 & 0.3028 & 0.3934 & 29.91 \\
\hline 2 & 0.5861 & 0.4228 & -38.63 & 0.3974 & 0.2897 & -27.10 & 0.6403 & 0.4262 & -33.44 & 0.2919 & 0.4335 & 48.49 \\
\hline 3 & 0.3997 & 0.4133 & 3.28 & 0.2752 & 0.2834 & 2.98 & 0.7739 & 0.5968 & -22.88 & 0.4033 & 0.5212 & 29.23 \\
\hline 4 & 0.5741 & 0.4214 & -36.24 & 0.38 & 0.2887 & -25.87 & 0.6728 & 0.3854 & -42.72 & 0.2653 & 0.4547 & 71.42 \\
\hline 5 & 0.5636 & 0.4988 & -13.00 & 0.3827 & 0.3393 & -11.34 & 0.7268 & 0.5404 & -25.65 & 0.3664 & 0.4901 & 33.75 \\
\hline 6 & 0.6379 & 0.4458 & -43.07 & 0.4314 & 0.3047 & -29.38 & - & - & - & - & - & - \\
\hline 7 & 0.6837 & 0.5265 & -29.86 & 0.4615 & 0.3574 & -22.56 & - & - & - & - & - & - \\
\hline average & 0.5813 & 0.4535 & -28.20 & 0.3943 & 0.3097 & -20.15 & 0.6786 & 0.4784 & -29.64 & 0.3260 & 0.4586 & 42.56 \\
\hline
\end{tabular}

Table 6. The results of SAVI and TSAVI analyzes for Domaniowski reservoir. Source: own elaboration.

\begin{tabular}{|c|c|c|c|c|c|c|}
\hline \multirow{2}{*}{$\begin{array}{c}\text { Test } \\
\text { field }\end{array}$} & \multicolumn{6}{|c|}{ Domaniowski Reservoir } \\
\cline { 2 - 7 } & $\begin{array}{c}\text { SAVI } \\
1994\end{array}$ & $\begin{array}{c}\text { SAVI } \\
2016\end{array}$ & $\begin{array}{c}\text { Change } \\
\%\end{array}$ & $\begin{array}{c}\text { TSAVI } \\
1994\end{array}$ & $\begin{array}{c}\text { TSAVI } \\
2016\end{array}$ & $\begin{array}{c}\text { Change } \\
\%\end{array}$ \\
\hline 1 & 0.496 & 0.452 & -8.85 & 0.340 & 0.309 & -9.01 \\
\hline 2 & 0.391 & 0.350 & -10.28 & 0.270 & 0.243 & -10.2 \\
\hline 3 & 0.441 & 0.302 & -31.6 & 0.303 & 0.211 & -30.42 \\
\hline 4 & 0.445 & 0.299 & -32.94 & 0.306 & 0.209 & -31.71 \\
\hline 5 & 0.363 & 0.284 & -21.72 & 0.252 & 0.199 & -20.88 \\
\hline 6 & 0.599 & 0.380 & -36.61 & 0.407 & 0.262 & -35.74 \\
\hline average & $\mathbf{0 . 4 5 6}$ & $\mathbf{0 . 3 4 4}$ & $\mathbf{- 2 3 . 6 7}$ & $\mathbf{0 . 3 1 3}$ & $\mathbf{0 . 2 3 9}$ & $\mathbf{- 2 2 . 9 9}$ \\
\hline
\end{tabular}

\section{Conclusions}

In the conducted research, changes in the structure of land use surrounding the given water reservoir were analyzed along with an attempt to determine the dynamics of these processes. On the basis of analyzes performed using the $\mathrm{K}$ - means method, it was found that as a result of the construction of a water reservoir, at a distance of $500 \mathrm{~m}$ from the shoreline the percentages of built-up land, forests and wasteland in the total area of the terrain increase while the percentage share of agricultural land and pastures decreases.

For each of the analyzed objects, the trend was similar. The authors, however, believe that the impact of socio-economic changes on changes in land use should also be taken into account.

The subsequent analyzes focused on the analysis of changes in the NDWI (Normalized Difference Water Index), which determines the water content in plants. For this indicator, the most promising results were obtained. It was found that due to the construction of a water reservoir, the NDWI value increases from about 20 to $30 \%$, which means that the proportion of water in plants increases.

On the basis of the analysis of changes in the SAVI (Soil Adjusted Vegetation Index) and TSAVI (Transformed Soil Adjusted Vegetation Index) indices, it was found that these indices, correlated with the state of vegetation, as a result of the construction of water reservoirs decreased respectively from 20 to $30 \%$ in the case of SAVI and from 20 to nearly 40 in the case of TSAVI.

Summarizing, it can be assumed that the above mentioned indices are useful for modelling the impact of construction of water reservoirs on the surrounding environment. On the basis of satellite data, the percentage impact of water reservoirs on the change in NDWI, SAVI, TSAVI values or land use change was determined. In order to obtain more accurate results, the authors postulate an increase in the number of observations and analysis of results from many years, both before and after the construction of water reservoirs.

\section{References}

1. Krajowy Zarząd Gospodarki Wodnej, Diagnosis of the current state of water management (In Polish: Diagnoza aktualnego stanu gospodarki wodnej). Warszawa: Krajowy Zarząd Gospodarki Wodnej, (2010)

2. B. Werner, European waters - current status and future challenges. Copenhagen: European Enviroment Agency, (2012)

3. M. Bodziony, Computer aided design of retention systems delaying flood outflow from the mountain catchment (In Polish: Komputerowe wspomaganie projektowania systemów retencji opóźniających odpływ powodziowy ze zlewni górskiej). Politechnika Krakowska, (2005)

4. A. Byczkowski, Hydrology (In Polish: Hydrologia), Vol. I and II. Warszawa: Wydawnictwo SGGW, (1992)

5. A. Ciołkosz, A. Kęsik, Satellite remote sensing (In Polish: Teledetekcja satelitarna). Warszawa: PWN (1989)

6. M. Szostak, P. Weżyk, P. Hawryło Spatio-temporal land use and land cover changes of the Błędów Desert (In Polish: Przestrzenno-czasowe zmiany pokrycia i użytkowania terenu Pustyni Błędowskiej). Problemy leśnictwa w górach i 
regionach przemysłowych, Wydawnictwo Uniwersytetu Rolniczego w Krakowie, Kraków, pp. 103-113 (2015)

7. M. Szostak, P. Wężyk, P. Hawryło, M. Pietrzykowski, The analysis of spatial and temporal changes of land cover and land use in the reclaimed areas with the application of airborne orthophotomaps and LANDSAT images. Geodesy and Cartography, 64, 1, pp. 75-86 (2015)

8. I. Piech, B. Drożdz, Satellite imagery as a source of information about landscape (In Polish: Obrazy satelitarne jako źródło informacji o krajobrazie), Infrastruktura i Ekologia Terenów Wiejskich, No 3/2010, Polska Akademia Nauk, Oddział w Krakowie, pp. 41-54.

9. J. Niedzielko, S. Lewiński, Land cover change detection using Landsat imagery- comparison of three methods (In Polish: Detekcja zmian pokrycia terenu na zdjęciach satelitarnych Landsat porównanie trzech metod). Teledetekcja Środowiska, Warszawa (2012). ISSN 0071-8076

10. J. Tou, Pattern Recognition Principles. Londyn: Addison-Wesley Publishing Company, pp. 353-354 (1974)

11. C. Tucker, Monitoring the grassland of the Sahel. International Journal of Remote Sensing, 7, pp. 1571 - 1581 (1984)

12. A. Richardson, J. Everitt, Using spectral vegetation index to estimate rangeland productivity. Geocarto International, 1, pp. 63-77 (1992)

13. J. Lyou, D. Yaun, L. Ross, A change detection experiment using Vegetation Indices. Photogrammetric Engineering \& Remote Sensing, 64, 2, pp. 143-150 (1998)

14. P. Ceccato, Detecting vegetation water content using reflectance in the optical domain. Remote Sensing of Enviroment, 77, pp. 22-33 (2001)

15. L. Shunling, L. Xiaowen, J. Wang, Advanced Remote Sensing. Amsterdam: Elsevier, (2012).

16. Z. Bonczar, R. Kostuch, R. Kwiecień, B. Kwoczyńska, Ł. Popławski, J. Słupek , E. Stanke, A. Szymacha, Impact on the environment of the newly built Domaniów reservoir on the Radomka River (In Polish: Oddziaływanie na środowisko nowo wybudowanego zbiornika wodnego Domaniów na rzece Radomce), monograph from the series Infrastruktura i Ekologia Terenów Wiejskich. PAN Komisja Technicznej Infrastruktury Wsi, Kraków, 4 (2004)

17. G. Bo-Cai , NDWI - a Normalized Difference Water Index for Remote Sensing of Vegetation Liquid Water from space. Journal of Remote Sensing of Enviroment, pp. 257-266 (1996)

18. Z. Kurczyński, Photogrammetry (In Polish: Fotogrametria). Warszawa: PWN, (2014).

19. Digital Glob (2017). [Online] 07 may 2017. https://digitalglobe.com.
20. N. Nargess Memarsadehi, S. Netanahu, J. Le Moigne, A fast implementation of the ISODATA clustering algorithm. International Journal of Computational Geometry \& Applications, pp. 71103 (2007)

21. J. Rouse, Monitoring the vernal advancment and retrogradation (green wave effect) of natural vegetation. Austin: Remote Sensing Center, Texas, (1973)

22. O. Lillesaeter, Spectral reflectance of partly transmitting leaves: Laboratory measurements and mathematical modeling. Remote Sensing of Enviroment, 12, pp. 247 - 254 (1982)

23. A. Huete, „A soil-adjusted vegetation index (SAVI)". Remote Sensing of Environment, 25, pp. 259-309 (1988)

24. F. Baret, G. Guyot, TSAVI: a vegetation index which minimizes soil brightness effects on LAI and APAR estimation. Geoscience and Remote Sensing Symposium, IGARSS'89, 12th Canadian Symposium on Remote Sensing. Vancouver : IEEE Xplore, pp. 1355-1358 (1989) 